phoryl chloride ${ }^{3,4)} \mathrm{S}=\mathrm{PCl}_{3}$, S-2-Carbamoylethyl phosphorothioate ${ }^{5)} \mathrm{H}_{2} \mathrm{~N}-\mathrm{C}-\mathrm{CH}_{2} \mathrm{CH}_{2} \mathrm{~S}-\mathrm{P}-\mathrm{CH}$ などを用いる方法が 報告されている。これらはいずれも単離操作の段階において DEAE セルロースカラムを用いるため, とりあつかえる 量に限度があり，またカラムを用いても無機のチオリン酸を除去しにくい久点がある。結局バリウム塩にして溶解度差 を利用して単離している。本法6) はカラムを用いないため時間の節約ならび多量に単離することができ，しかも単離収 率が高いところに特色がある。

\title{
引用文献
}

1) R. Lohrmann, H.G. Khorana, J. Am. Chem. Soc. 864188 (1964)

2) F. Eckstein, J. Am. Chem. Soc. 884292 (1966); Tetrahedron Lett. 1967 1157, 3495

3) A. Hampton, L.W. Brox, M. Bayer, Biochemistry 82303 (1969)

4) K. Haga, M. Kainosho, M. Yoshikawa, Bull Chem. Soc. Japan 44460 (1971)

5) A.F. Cook, J. Am. Chem. Soc. 92190 (1970)

6) T. Hata, I. Nakagawa, Bull. Chem. Soc. Japan 433619 (1970)

\section{4-tert-Butyl-4'-tosyldiphenyl ether}

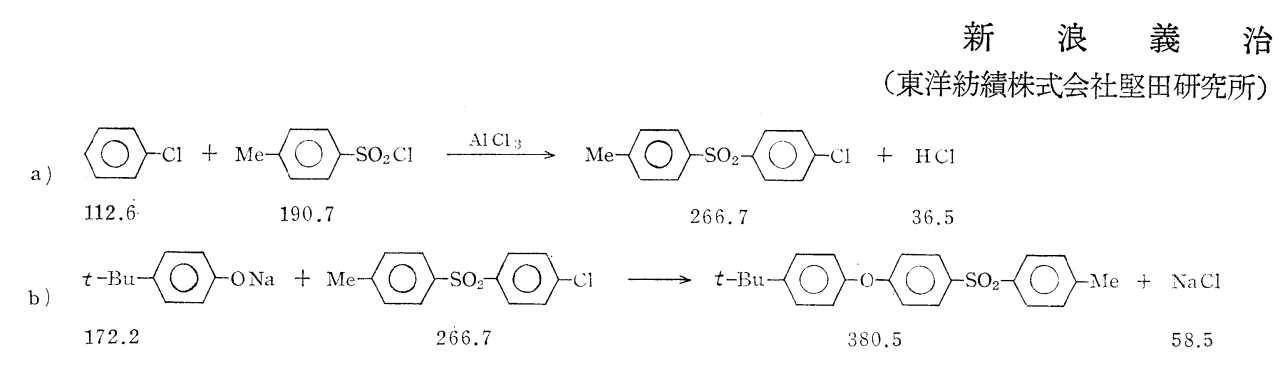

\section{I. 製 法}

a) p-tosylchlorobenzene

かきまぜ機, 窒素ガス導入口をかねた試薬投入口, 還流冷却管および温度計を備えた $500 \mathrm{~m} l$ の四つロフラスコに, $p$-toluenesulfonyl chloride (注意 1 ) $95.4 \mathrm{~g}(0.50 \mathrm{~mol})$ と chlorobenzene (注意 2$) 113 \mathrm{~g}(1.00 \mathrm{~mol})$ を入れ $70^{\circ} \mathrm{C}$ に加温して溶解する。ついで窒素ガスを通じながら無水塩化アルミニウム（注意 3$) 80 \mathrm{~g}(0.60 \mathrm{~mol}$ )を 1 時間を要し てじょじょに添加する。このとき発生する塩化水素ガスは系外の水酸化ナトリウム溶液に吸収させるょうにする。添加 終了時には内温は $100 \sim 110^{\circ} \mathrm{C}$ に到達する。さらにこの温度でかくはん下に 2 時閒反応させる。反応終了後内容物を氷 水 $1 \mathrm{~kg}$ 中に注ぐと白色の固型物が得られる。これをメタノールから再結晶すると収量 $93 \mathrm{~g} \sim 100 \mathrm{~g}(70 \sim 75 \%), \mathrm{mp} 128$ ${ }^{\circ} \mathrm{C}$ の $p$-tosylchlorobenzene ${ }^{1)}$ が得られる。

\section{b) 4-tert-butyl-4'-tosyldiphenyl ether}

かきまぜ機, 窒素ガス導入口をかねた試薬投入口, 蒸留装置および温度計を備えた $2 l$ の四つロフラスコに p-tert butylphenol（注意 4$) 75 \mathrm{~g}(0.50 \mathrm{~mol})$ と水酸化ナトリウム $20.8 \mathrm{~g}(0.52 \mathrm{~mol})$ をジメチルスルホキシド $500 \mathrm{~m} l$ (注 意 5 ）と混合し窒素ガスを通じながらかくはん下に $100^{\circ} \mathrm{C}$ に昇温して溶解し，ついでクロロベンゼン $125 \mathrm{ml}$ を加えて 反応の結果生成する水をクロロベンゼンと共沸させて系外に除去する。水およびクロロベンゼンが完全に除去されてか ら $150^{\circ} \mathrm{C}$ に昇温し, $p$-tosylchlorobenzene $133 \mathrm{~g}(0.50 \mathrm{~mol})$ をじょじょに添加する（注意 6 )。添加後窒素ガスを流し つづけながら，さらに 3 時間反応させる。こうして得られた反応物を氷水 $3 \mathrm{~kg}$ 中によくかきまぜながら，じょじょに 注入すると白色の固形物が得られる。これをアセトンから再結晶すると収量 $152 \sim 162 \mathrm{~g}$ (80〜85\%), mp 131 ${ }^{\circ} \mathrm{C}$ の $4-$ tert-butyl-4'-chlorodiphenyl ether が得られる。

\section{II. 注 意事 項}

（1）水分含有量の低い新しい試薬ならそのまま使用してよいが，長期間貯蔵されたものは $n$-へキサンで再結晶し て用いる。 
（2）市販一級品を脱水し，さらに蒸留で精製する。

（3）市販一級品をこまかくくだいて使用する。

（4）市販一級品を使用前に十分乾燥する。

（5）市販一級品を使用前に蒸留で精製する。

（6）急激に添加するとはげしい反応が起り危険である。

\section{III. 性 質}

$\mathrm{mp} 131^{\circ} \mathrm{C}$ 。ジオキサン，アセトン，ベンゼン，二塩化エチレン，酢酸エチル，ジメチルスルホキシドに易溶。メタノ 一ル, エタノールに難溶。水にはほとんど溶解しない。

IR (KBr)；1310, 1299, 1283, 1243, 1153, $1104 \mathrm{~cm}^{-1}$ 。

この化合物を二塩化エチレンに溶解し無水硫酸を反応させることによってモノスルホン化物が容易に得られる。

\section{IV. 本法の利点}

a) で合成される $p$-tosylchlorobenzene ${ }^{1)}$ はすでに合成されているが簡単な報告のため収率等詳しいことは不明で ある。また b) で合成される 4-tert-butyl-4'-tosyldiphenyl ether は新規化合物である。

芳香族エーテル化合物の合成法としては一般には古くから Ullman の方法 ${ }^{2)}$ が知られているが，かこくな条件を必要 とし，しかも収率が低い。これに反して本方法のようにトシル基によって活性化されている芳香族ハロゲン化合物はフ エノール類と温和な条件でも縮合し高収率で芳香族エーテルが得られる。

本法においてフェノール成分を変えることによってしゅじゅの新規化合物が容易に合成できる。なおこの方法はポリ アリールエーテルの合成に用いられている方法 ${ }^{3)}$ に準きょしたものである。

\section{引用文献}

1) C.A. Buehler, J.E. Masters, J. Org. Chem. 4262 (1939)

2) F. Ullman, P. Sponagel, Ann 35083 (1906)

3) R. N. Johnson, A.G. Farnham, R.A. Clendinning, W.F. Hale, C.N. Merriam, J. poly Scie. (A-1) 52375 (1967)

\section{Tricyclo $\left[4 \cdot 3 \cdot 1 \cdot 1^{3,8}\right]$ undec $-4-$ ene \\ (4-Homoadamantene)}

有松正治 (京都大学工学部)

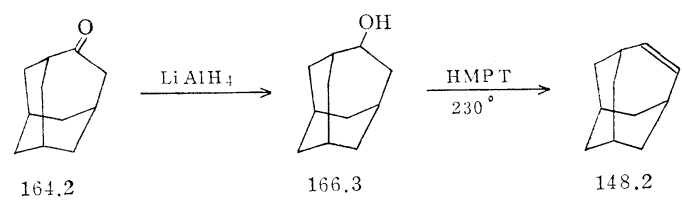

\section{I. 製 法}

\section{(a) 4-homoadamantanol}

滴下漏斗, 還流冷却器 (注意 1 ) をつけた内容 $200 \mathrm{ml}$ のフラスコに, lithium aluminum hydride $0.76 \mathrm{~g}(0.02 \mathrm{~mol}$ ), 無水エーテル $50 \mathrm{ml}$ をとり，マグネチックスターラーでかきまぜながら，4-homoadamantanone $1.64 \mathrm{~g}(0.01 \mathrm{~mol})$ （注意 2 ）を無水エーテル $20 \mathrm{ml}$ にとかした溶液を滴下する。滴下終了後, 12 時間加熱還流する。冷却後, 過 剩の lithium aluminum hydride を, 酢酸エチル $2 \mathrm{ml}$, つぎに $10 \%$ 塩化アンモニウム水溶液 $10 \mathrm{~m} l$ を加えて分解し（注意 3 ), 沈殿をロ別する。エーテル層を飽和食塩水で 3 回洗浄し, 無水硫酸ナトリウムで乾燥する。溶媒を留去し, 得ら れた結晶を減圧昇華 (油浴温度約 $150^{\circ} \mathrm{C}$, 減圧度 $2 \mathrm{mmHg}$ ) すると, 4-homoadamantanol $1.20 \mathrm{~g} \sim 1.28 \mathrm{~g}(72 \sim 77 \%$ ) が得られる。 $\mathrm{mp} 265 \sim 266^{\circ} \mathrm{C}$ (文献值 ${ }^{1)} 267.0 \sim 268.0^{\circ} \mathrm{C}$ )。 